\title{
Integrated marketing communication "Gadis modis" sebagai usaha mikro kecil dan menengah dalam meningkatkan loyalitas konsumen
}

\author{
Indriana Akhyani ${ }^{\mathrm{a}, 1, *}$ \\ ${ }^{a}$ Himpunan Mahasiswa Ilmu Komunikasi Universitas Ahmad Dahlan \\ ${ }^{1}$ Indrianaa@comm.uad.ac.id*; \\ * corresponding author
}

Article history

Received 30-06-2020

Revised 01-07-2020

Accepted 02-07-2020

Keywords

UMKM

Integrated Marketing communication

Loyatitas konsumen

\begin{abstract}
Penelitian ini bertujuan untuk menjabarkan strategi yang dibuat oleh Gadis Modis sendiri untuk meningkatkan loyalitas konsumen dalam pembelian sebuah produk dan mampu memaksimalkan proses transaksi jual beli. Metode Penelitian yang digunakan adalah Kualitatif Deskriptif yang bertujuan untuk mendapatkan gambaran secara mendalam berdasarkan situasi yang nyata dari apa yang diteliti. Teknik pengumpulan data dilakukan dengan cara observasi, wawancara, dan dokumentasi. Penelitian melakukan analisis data dengan menelaah datadata yang diperoleh dari hasil observasi, wawancara, dan dokumentasi. Untuk menguji keabsahan data, peneliti melakukan dengan cara membandingkan, menyatukan, dan menggabungkan seluruh data yang telah diperoleh. Hasil dari Penelitian ini adalah Gadis Modis sampai saat ini telah melakukan bahkan melaksanakan sejumlah strategi pemasaran diantaranya dengan melaksanakan komunikasi pemasaran terpadu (Integrated Marketing communication) yang meliputi Promotion (promosi), Public Relations (Humas), Advertising, Direct Marketing, Personal selling, Publicity, Event, Interactive Marketing untuk mengkomunikasikan visi dan misi yang ada pada perusahaan.
\end{abstract}

This is an open access article under the CC-BY-SA license.

\section{Introduction}

Di Era yang Modern ini teknologipun tentunya ikut berkembang, begitu pula dengan perkembangan fashion yang tak ada hentinya, semakin berjalannya waktu pakaian seakan menjadi kebutuhan yang sangat pokok bagi setiap individu. Pakaian sangat dibutuhkan oleh manusia pada zaman sekarang karena merupakan suatu hal yang dapat menunjang kepercayaan diri seseorang, maka dari itu pada saat ini banyak sekali kita melihat bahkan menjumpai banyak sekali store fashion online maupun offline (Bhardwaj \& Fairhurst, 2010). Hal tersebut dikarenakan banyaknya distributor atau UMKM( usaha mikro kecil dan menengah) yang menjual berbagai macam jenis pakaian, dan menurut Kementrian Perindustrian Nasional mencatatkan Dari sekitar 56,5 juta UMKM, lebih dari 50 persen ada di pulau Jawa, menurutData Badan Pusat Statistik (BPS) menunjukkan, pada tahun 2013 tenaga kerja yang terserap di Indonesia sebanyak 110.801.648 juta orang. Dari jumlah itu, 11.872.428 orang terserap ke sektor industri kreatif melalui UMKM dan lebih dari 60 persen tenaga kerjanya berada di Jawa. Jika dilihat dari data yang dimiliki Kementrian Perindustrian UMKM memang sangat berkembang pesat di zaman yang modern ini, terlebih lagi karena adanya jaringan internet dan dengan adanya media sosial yang memudahkan bahkan mampu memenuhi kebutuhan seseorang dalam melakukan transaksi jual beli. 
Toko online sangat identik dengan UMKM, maka dari itu Gadis modis memproduksi pakaian yang sesuai dengan kebutuhan wanita dan selalu berdasarkan trend fashion di saat ini. Wanita yang ingin tampil cantik dan anggun tanpa harus bersusah payah keluar dari rumah agar mampu membeli kebutuhannya tersebut tentunya sangat di untungkan dengan adanya online shop (Lee, Shi, Cheung, Lim, \& Sia, 2011). Gadis Modis mampu memenuhi keinginan para wanita terutama untuk para wanita muslim yang ingin membeli baju dengan kualitas premium namun dengan harga yang relatif standar atau murah, tak hanya itu Gadis Modis juga memproduksi berbagai jenis pakaian yang mampu digunakan oleh wanita muslim maupun wanita non muslim (Al-Halah, Stiefelhagen, \& Grauman, 2017), contohnya seperti kemeja, khimar, jilbab, maupun gamis syar'i. Tak hanya itu Gadis Modis juga memproduksi tas bagi kaum perempuan, tak menutup kemungkinan bahwa tuntutan dari konsumen dan tren fashion di Indonesia (Pittman \& Reich, 2016).

\section{Theorotocal Framework}

\subsection{Komunikasi Pemasaran}

Dalam setiap kegiatan pemasaran terdapat elemen yang sangat penting yaitu komunikasi. Dengan adanya komunikasi setiap kegiatan pemasaran akan berlangsung dengan sedemikian rupa dan dapat mencapai segala sesuatu yang diinginkan oleh kedua belah pihak salah satunya dalam hal pembelian (Neal, 2009).

1) Pengertian strategi komunikasi pemasaran

Strategi pemasaran adalah sebuah pola pikir pemasaran yang akan digunakan untuk mencapai sebuah tujuan pemasarannya. Strategi Pemasaran didalamnya terdapat strategi spesifik untuk pasar sasaran, penetapan posisi, bauran pemasaran dan besarnya pengeluaran dalam pemasaran (Kotler \& Keller, 2009).

\section{a) Model Komunikasi Pemasaran}

Komunikasi pemasaran yaitu sebuah usaha untuk menyampaikan pesan kepada khalayak terutama konsumen atau yang menjadi sasaran pasar mengenai keberadaan produk tersebut. Konsep yang secara umum sering digunakan untuk menyampaikan pesan disebut sebagai bauran promosi (promotional mix) (Castronovo \& Huang, 2012).

\section{b) Bentuk Strategi Komunikasi Pemasaran}

Agar mencapai sasaran komunikasi yang baik komunikator dapat memilih salah atu dari beberapa media, tergantung pada tujuan yang akan dicapai, pesan yang akan disampaikan kepada konsumen, dan teknik yang digunakan, karena beberapa media komunikasi itu tidak dapat disamakan dengan pasti sebab masing-masing mempunyai kelebihan dan kekurangan satu sama lain. Komunikasi pemasaran adalah hal yang penting dalam memperkenalkan, menginformasikan, menawarkan suatu produk, dan mempengaruhi masyarakat mengenai suatu produk. Mengembangkan Komunikasi Pemasaran Yang Efektif. Ada 8 langkah untuk mengembangkan program komunikasi dan promosi yang efektif.

\section{c) Komunikasi Pemasaran Terpadu (IMC)}

Pada saat ini Integrited Marketing Communication adalah sebuah konsep dalam perencanaan komunikasi pemasaran yang memiliki nilai rencana yang lebih mudah dipahami, misalnya seperti periklanan, respon langsung, sales promotion, dan PR yang mengombinasikan hal-hal tersebut agar memberikan kejelasan, konsistensi dan dampak komunikasi yang maksimal, atau secara singkatnya bisa diartikan sebagai Proses dari pengelolaan customer relationships yang menggerakkan brand value (Thorson \& Rodgers, 2019).

\section{d) Strategi Komunikasi Pemasaran Terpadu}

Pada bagian inilah penulis akan menjelaskan mengenai strategi komunikasi pemasaran terpadu. Strategi merupakan rencana cermat dan sistematis mengenai suatu kegiatan untuk mencapai sasaran khusus. 


\section{Method}

Jenis penelitian ini menggunakan jenis metode penelitian Kualitatif yang bersifat deskriptif. Dari hal tersebut terdapat empat inti yang harus diperhatikan yaitu ilmiah, data, tujuan dan kegunaan. Metode penelitian adalah suatu cara ilmiah untuk mendapatkan data dengan tujuan kegunaan tertentu (Sugiyono, 2016). UMKM Gadis Modis Jalan Kota Gede Yogyakarta. Penelitian ini akan dilakukan selama 2 bulan dari bulan juli 2019 sampai bulan Agustus 2019. Pengumpulan data, yaitu mengumpulkan data dilokasi penelitian dengan melakukan observasi, wawancara, dan dokumentasi dengan menentukan strategi pengumpulan data yang dipandang tepat dan untuk menentukan fokus serta pendalaman data pada proses pengumpulan data (Sugiyono, 2014). (1) Reduksi data , yaitu sebagai proses seleksi, penfokusan, transfortasi datakasar yang ada dilapangan langsung, dan diteruskan pada waktu pengumpulan data, dengan demikian data dimulai sejak penelitian mefokuskan objek penelitian dan lokasi penelitian. (2) Penyajian data, yaitu rangkaian informasi yang memungkinkan sebuah penelitian dilakukan. Penyajian data diperoleh berbagai jenis. (3) Penarikan kesimpulan, yaitu dalam pengumpulan data, peneliti harus mengerti dan paham terhadap sesuatu yang di teliti langsung dilapangan dengan menyusun pola-pola pengarahan dan sebab akibat. Trianggulasi adalah cara yang paling umum digunakan dalam penjaminan validitas data dalam penelitian kualitatif. Trianggulasi adalah teknik pemeriksaan keabsahan data dengan memanfaatkan sesuatu yang diluar data itu untuk keperluan pengecekan data atau sebagai pembanding data itu.

\section{Result and Discussion}

\section{1) Aktivitas penjualan Gadis Modis}

Anggun Aprilia selaku owner dari gadis modis. Dimana pekerjaannya atau tugasnya disini adalah mengendalikan secara penuh sistem yang ada di dalam perusahaan yang ia bangun, mulai dari mengelola perusahaan tersebut, sampai bertanggung jawab atas keuntungan maupun kerugian yang ada didalam perusahaan tersebut. Terlepas dari tugasnya dalam menjaga operasional perusahaan, owner juga bertanggung jawab penuh atas segala aktivitas yang ada di store Gadis Modis salah satunya yaitu menjalankan aktivitas dalam strategi pemasaran maupun dalam strategi promosi perusahaan dalam upaya mempertahankan loyalitas konsumen terhadap kompetitor yang ada di Yogyakarta dan daerah lainnya.

\section{2) Strategi pemasaran dan promosi}

\section{a) Bauran Pemasaran}

Bauran pemasaran merupakan alat yang digunakan oleh suatu perusahaan untuk pemasaran. Bauran pemasaran terdiri dari sesuatu perusahaan yang mempu mempengaruhi segmentasinya dengan mengajak, mempengaruhi, hingga membeli produk yang dipasarkan. Perkembangan bauran pemasaran dari $4 \mathrm{P}$ menjadi $7 \mathrm{P}$ adalah bentuk strategi yang saat ini sangat dibutuhkan dalam melakukan pemasara, hingga menjadi analisis pada permasalahn yang ada. Integrited Marketing Communication sebagai strategi Komunikasi Gadis Modis dalam meningkatkan loyalitas konsumen

IMC adalah konsep suatu perusahaan harus secara hati-hati mengintegrasikan dan mengkoordinasikan saluran komunikasinya untuk menyampaikan pesan yang jelas, konsisten, dan mampu meyakinkan mengenai perusahaan maupun produknya (Kotler \& Armstrong, 2001, hal. 138). IMC sangat lekat dengan dunia pemasaran maka dari itu strategi IMC yang sering digunakan oleh UMKM adalah advertising atau periklanan. Selain dapat dijadikan sebagai sarana pemasaran produk. Melalui iklan yang sering dilihat dan terus menerus dilakukan setidaknya akan membuat promosi suatu produk mampu dilirik dan diingat oleh konsumen. Jika dilihat pada saat ini dengan jumlah pengguna sosial media berbasis chat yang banyak dan semakin hari semakin bertambah mampu membuka peluang bagi UMKM seperti Gadis Modis untuk mengembangkan pasaran menggunakan smartphone. 


\section{Conclusion}

UMKM bisa dibilang sebagai salah satu penunjang perekonomi bagi negara seperti Indonesia dalam hal ini sebuah pelaku usaha bisnis, Gadis Modis sebagai perusahaan yang berdiri dibidang fashion yang merupakan UMKM yang bisa terbilang perkembangannya sangat pesat di Yogyakarta. Semua produk yang dijual berkisar mulai 20 sampai 350 ribu rupiah sehingga Gadis modis sampai saat ini memiliki pendapatan dibawah 50 juta rupiah maka dari itu digolongkan kedalam UMKM. Strategi pemasaran yang dilakukan oleh Gadis Modis dalam memasarkan produknya yaitu dengan menggunakan strategi pemasaran IMC yang meliputi: Promotion (promosi), Public Relations (Humas), Advertising, Direct Marketing, Personal selling, Publicity, Event, Interactive Marketing. Selain itu Gadis Modis juga mengembangkan bauran pemasaran atau marketing mix yang terdiri dari 4 unsur yaitu produk atau product, harga atau price, tempat atau place, dan promosi atau promotion. Bauran Pemasaran 4P Gadis Modis: Keberhasilan perusahaan dibidang pemasaran yang terkait dengan keberhasilannya dalam menentukan sebuah produk yang tepat, harga yang layak, saluran distribusi yang baik, dan promosi yang efektif.

\section{References}

Al-Halah, Z., Stiefelhagen, R., \& Grauman, K. (2017). Fashion Forward: Forecasting Visual Style in Fashion. Proceedings of the IEEE International Conference on Computer Vision. https://doi.org/10.1109/ICCV.2017.50

Bhardwaj, V., \& Fairhurst, A. (2010). Fast fashion: Response to changes in the fashion industry. International Review of Retail, Distribution and Consumer Research. https://doi.org/10.1080/09593960903498300

Castronovo, C., \& Huang, L. (2012). Social Media in an Alternative Marketing Communication Model. Journal of Marketing Development and Competitiveness.

Kotler, P., \& Keller, K. L. (2009). Manajemen pemasaran Jilid 1. In Jakarta.

Lee, M. K. O., Shi, N., Cheung, C. M. K., Lim, K. H., \& Sia, C. L. (2011). Consumer's decision to shop online: The moderating role of positive informational social influence. Information and Management. https://doi.org/10.1016/j.im.2010.08.005

Neal, C. P. (2009). Marketing management. Marketing Management. https://doi.org/10.4324/9781315842783-16

Pittman, M., \& Reich, B. (2016). Social media and loneliness: Why an Instagram picture may be worth more than a thousand Twitter words. Computers in Human Behavior. https://doi.org/10.1016/j.chb.2016.03.084

Sugiyono. (2014). Teknik Pengumpulan Data. Metode Penelitian Kuantitatif, Kualitatif Dan R\&D. https://doi.org/10.3354/dao02420

Sugiyono. (2016). Memahami Penelitian Kualitatif. Bandung: Alfabeta.

Thorson, E., \& Rodgers, S. (2019). Advertising. In An Integrated Approach to Communication Theory and Research, Third Edition. https://doi.org/10.4324/9780203710753-17 